\title{
Effect of convective and microwave methods on drying characteristics, color, rehydration and microstructure properties of ginger
}

\author{
Nazmi IZLI ${ }^{1 \star}$ (D), Ahmet POLAT ${ }^{1}$
}

\begin{abstract}
In this research, the effects of convective drying method $\left(60,70\right.$ and $\left.80^{\circ} \mathrm{C}\right)$ and microwave drying method $(160$ and $350 \mathrm{~W})$ on the drying characteristics, color, rehydration and microstructure properties of ginger has been examined. For the purpose of choosing the most appropriate thin-layer drying models in terms of the drying applications, nine mathematical models have been applied on the experimental data. Pursuant to the assessment of the statistical tests, models of Diffusion Approach, Midilli et al. and Page that represent drying characteristics are found to be better than other models. Drying applications have affected the color values of all fresh ginger samples. Results indicated that browning degree increases as drying temperature and microwave power rise. The samples dried at $60^{\circ} \mathrm{C}$ has the maximum rehydration ratio while the samples dried at $80^{\circ} \mathrm{C}$ has the minimum rehydration ratio. Scanning electron microscopy visuals have ascertained that the deterioration of the ginger samples remarkably surged due to the rise in either drying temperature or microwave power. Applying the convective and microwave techniques as an alternative drying method for ginger samples is possible.
\end{abstract}

Keywords: color; drying characteristics; ginger; rehydration ratio; scanning electron microscopy.

Practical Applications: The optimum drying conditions of ginger samples were adjusted at $60{ }^{\circ} \mathrm{C}$ for the convective drying method and $160 \mathrm{~W}$ power level for the microwave drying method.

\section{Introduction}

Ginger, which has been known as a spice all around the world for ages, is extensively used as a condiment or spice in a wide range of compound drinks and food (An et al., 2016). Additionally, ginger has several benefits to health and that enables its extensive usage in newly developing nutraceuticals and functional foods markets which offer various commercial natural products (Simon-Brown et al., 2016). Ginger embodies an essential oil that has an aroma, an oleoresin (gingering) elicits the effective smell, gums, starch, carbohydrate, proteins, fiber and minerals (Deshmukh et al., 2013). Ginger is commercially available in fresh and processed forms, including dried product, concentrated ginger powder and juice (Akpinar \& Toraman, 2016).

Drying is an important operation in ginger processing (Thorat et al., 2012). Ginger spices, medicine, and cosmetics that comprise ginger, soft drinks and candies that have ginger flavor can be produced by using dried ginger (An et al., 2016). Drying which offers several benefits, for instance extending shelf life, minimizing volume for storage, and reducing weight for delivery. It is one of the oldest ways to conserve foods (Parlak, 2015). Various methods can be applied in order to obtain dried vegetables and fruits. The most common method used for drying is convective drying, because of its simplicity and investment and operation costs. On the other hand, if the drying conditions are not under control, (for instance, very high temperatures and long periods) this may result in the deterioration of thermo-sensitive components which would lead to dissipation of nutritional and sensory attributes if drying conditions are not kept under control (Wojdyło et al., 2016). For the post-harvesting process of agricultural products, microwave drying method is among the most efficient methods. The three major features that the microwave drying method has high end-product quality, low power consumption, and time efficiency which will be in favor of the drying industry (Pu et al., 2016). In other respects, microwave drying method contains obvious drawbacks including high initial cost, non-uniform heating, loss in quality and limited penetration of microwaves into the product (Zielinska et al., 2015). After conducting a literature review it is seen that there are not many researches has been done on the drying process of ginger samples.

Main purposes of this research are to probe into the drying kinetics of ginger samples that are dried by means of various drying methods (convective and microwave), to inspect variances in terms of color between fresh product and dried product, to choose best thin-layer drying models, and ultimately to interpret the effects of drying applications on rehydration and microstructure properties of ginger samples.

\section{Materials and methods}

\subsection{Drying equipment and procedure}

Fresh ginger samples used in the study were bought from a local bazaar in Bursa, a province of Turkey, then they were stored at $4 \pm 0.5^{\circ} \mathrm{C}$ up to the completion of the experiments. 
Fully grown and healthy gingers were used in the applications over the course of this study. Prior to the drying processes, the ginger samples were first sliced into cubes $\left(0.7 \mathrm{~cm}^{3}\right)$ using a dicer (Börner, Wingene, Belgium) and dried in this form (Oikonomopoulou \& Krokida, 2012). It was calculated that the ginger samples had an initial moisture level of 8.43 (g water $g$ dry matter ${ }^{-1}$ ) on a d.b. (dry basis) by use of forced-air convection oven (ED115 Binder, Tuttlingen, Germany) operates at $105^{\circ} \mathrm{C}$ for a duration of 24 hours.

The drying process was run in a modified laboratory convectivemicrowave oven (Whirlpool AMW 545, Italy). The mechanism was operated in convective mode at 60,70 and $80^{\circ} \mathrm{C}$ air temperatures in return and at $1 \mathrm{~m} \mathrm{~s}^{-1}$ air velocity; and also in microwave mode at 160 and $350 \mathrm{~W}$ output power levels in return. The drying applications in question were implemented within an area of $210 \times 450 \times 420 \mathrm{~mm}$ that is composed of a rotating glass plate which has $400 \mathrm{~mm}$ diameter located at the oven base. For the determination of mass, a digital balance (Radwag, Radom, Poland) with a sensitivity of $0.01 \mathrm{~g}$ was positioned under the oven (Horuz \& Maskan, 2015). The above-mentioned experiments were conducted in three copies.

\subsection{Mathematical modeling of drying data}

The data of moisture ratio was in line with the 9 thin layer models which were broadly utilized in the modeling of drying characteristics of ginger samples (Table 1). The equation located below was the formula that was utilized so as to figure out the moisture ratio $(M R)$ that the ginger samples had throughout the drying experiments (Aral \& Beşe, 2016):

$$
M R=\frac{M_{t}-M_{e}}{M_{o}-M_{e}}
$$

In the formula above $M_{t}$ is the moisture content ( $\mathrm{g}$ water $\mathrm{g}$ dry matter ${ }^{-1}$ ) at a given time, $M_{o}$ is the moisture content (g water g dry matter $\left.{ }^{-1}\right)$ at the beginning, and lastly $M_{e}$ is the moisture content ( $\mathrm{g}$ water $\mathrm{g}$ dry matter ${ }^{-1}$ ) at the equilibrium level. After it is examined in detail, the values of $M_{e}$ are rather smaller than $M_{t}$ or $M_{o}$. As a result, the formula for the moisture ratio was vulgarized as follows in a similar manner to some other research (Parlak, 2015):

$$
M R=\frac{M_{t}}{M_{o}}
$$

\subsection{Color measurement}

A colorimeter (MSEZ-4500L, HunterLab, Reston, Virginia, USA) was deployed to gauge the exact color of ginger samples both the dried and fresh ones. This exact color has been specified as a whole of $a$-values (redness/greenness), $b$-values (yellowness/blueness), and $L$-values (lightness). Color parameters for the samples of fresh ginger are $L_{0}^{*}, a_{0}^{*}$ and $b_{0}^{*}$. While performing the experiments, before each of the color measurements, by means of a standard white and black plate the colorimeter was calibrated. First of all, over the source of light, a glass cell that bears some amount of sample was put near to the nose cone of the colorimeter and then $L_{0}^{*}, a_{0}^{*}, b_{0}^{*}, a^{*}, b^{*}$ and $L^{*}$ values were noted down. Surface color of the sample was taken into account during the color reading operations, and finally, the color value was calculated as the mean of these ten color readings that were done at random positions of the ginger sample. Additionally, calculations of total color differences $\Delta \mathrm{E}$ [Eq. (3)] were performed applying the formula as follows (Tian et al., 2016):

$\Delta E=\sqrt{\left(L_{0}^{*}-L^{*}\right)^{2}+\left(a_{0}^{*}-a^{*}\right)^{2}+\left(b_{0}^{*}-b^{*}\right)^{2}}$

\subsection{Rehydration Ratio Measurement}

Rehydration ratio ( $\mathrm{R}$ ) is among the most important parameters of dried product quality and was calculated using Equation 4 as (Raghavan et al., 2008); where, $M_{1}$ and $M_{2}$ are sample weights (g) before and after rehydration, in return.

$R=\frac{M_{2}-M_{1}}{M_{1}}$

For rehydration ratio measurement, $3 \pm 0.1 \mathrm{~g}$ dried ginger sample was immersed in a glass beaker full of $400 \mathrm{~mL}$ of distilled water at $20^{\circ} \mathrm{C}\left( \pm 1^{\circ} \mathrm{C}\right)$ for $4 \mathrm{~h}$ (Doymaz, 2012). Then, the ginger samples were dewatered, blotted with tissue paper then weighed by use of an electronic digital balance (Radwag, Radom, Poland) with \pm 0.001 g accuracy.

\subsection{Microstructure analysis}

So as to monitor the effect of different drying methods on microstructures of ginger samples, a scanning electron microscopy (EVO 40, Carl Zeiss, Oberkochen, Germany) was used. Particles extracted from the dried samples were vertically

Table 1. Selected thin layer drying models used to mathematically model the ginger drying kinetics.

\begin{tabular}{clll}
\hline No & \multicolumn{1}{c}{ Model name } & \multicolumn{1}{c}{ Model } & \multicolumn{1}{c}{ References } \\
\hline 1 & Henderson \& Pabis & $M R=a \exp (-k t)$ & Celen et al. (2010) \\
2 & Newton & $M R=\exp (-k t)$ & Thorat et al. (2012) \\
3 & Page & $M R=\exp \left(-k t^{n}\right)$ & Demiray et al. (2017) \\
4 & Logarithmic & $M R=a \exp (-k t)+c$ & Parlak (2015) \\
5 & Two Term & $M R=a \exp \left(-k_{0} t\right)+b \exp \left(-k_{1} t\right)$ & Torki-Harchegani et al. (2016) \\
6 & Two Term Exponential & $M R=a \exp (-k t)+(1-a) \exp (-k a t)$ & Deshmukh et al. (2013) \\
7 & Wang \& Singh & $M R=1+a t+b t^{2}$ & Beigi (2016) \\
9 & Diffusion Approach & $M R=a \exp (-k t)+(1-a) \exp (-k b t)$ & Kaveh et al. (2017) \\
\hline
\end{tabular}


cut along the center of the pith and placed in the aluminum discs appropriately (Bondaruk et al., 2007). The samples were then coated with gold-palladium with a thickness of 40-50 nm under low vacuum $(20 \mathrm{kV})$ using a coating device (SCD-005, Baltec, Wetzlar, Germany), then their microphotographs were taken (Giri \& Prasad, 2007).

\subsection{Statistical analysis}

This study was performed by utilizing randomized plots factorial design of experimental type. Three replicates were used during the measurement process of the inspected components. To conduct an analysis of the results, JMP (Version 7.0, SAS Institute Inc., Cary, NC, USA) and MATLAB (MathWorks Inc., Natick, MA) software were used. Calculation of the mean differences and application of the LSD (Least Significant Difference) test to measure significance resulted in a significance level of 5\%. The model identifying the drying characteristics of ginger samples on thin layer best is the model with the highest coefficient of determination $\left(R^{2}\right)$ and the lowest reduced chi-squared $\left(\chi^{2}\right)$ and root mean square error (RMSE) values (Coşkun et al., 2017). The above-stated statistical variables are below:

$$
\chi^{2}=\frac{\sum_{i=1}^{N}\left(M R_{\text {exp }, i}-M R_{p r e, i}\right)^{2}}{N-n}
$$

$$
R M S E=\left[\frac{1}{N} \sum_{i=1}^{N}\left(M R_{p r e, i}-M R_{\mathrm{exp}, i}\right)^{2}\right]^{1 / 2}
$$

above, $M R_{\text {pre, },}$ means the forecasted moisture ratio in test number $\mathrm{i}$, $M R_{\text {exp }, i}$ means the experimental moisture ratio in test number i, $N$ means the count of constants existing in the drying model and also $n$ stands for the count of observations.

\section{Results and discussion}

\subsection{Drying kinetics of dried ginger}

Figure 1 depicts the drying curves of the ginger samples exposed to the conditions of convective drying method and microwave drying method. Analyzing the results of the test demonstrated that to attain the intended moisture content level under convective drying method drying durations of ginger samples at 60,70 and $80^{\circ} \mathrm{C}$ took 140,90 and 60 minutes, in return, while under microwave drying conditions, it took 100 minutes at $160 \mathrm{~W}$ microwave power level and it took 35 minutes at $350 \mathrm{~W}$ microwave power level. For ginger samples, the experiment results demonstrated that average total drying duration at $350 \mathrm{~W}$ took $65 \%$ less duration than that of at $160 \mathrm{~W}$. Moreover, as the air temperature rose from 60 to $80^{\circ} \mathrm{C}$, the drying duration of samples fell at a rate of $57.14 \%$, which signifies that the rise in either temperature or microwave power considerably reduce the drying duration. Beigi (2016) stated that quicker moisture evaporation and shorter drying time occur due to the fact that the speed of heat transfer between the sample and the thermal source is higher at higher temperatures. Horuz et al. (2017) reported that a $46.4 \%$ time reduction was observed when the microwave power surged from 120 to $180 \mathrm{~W}$ for tomato dying and they explained that the decrease in drying times with the
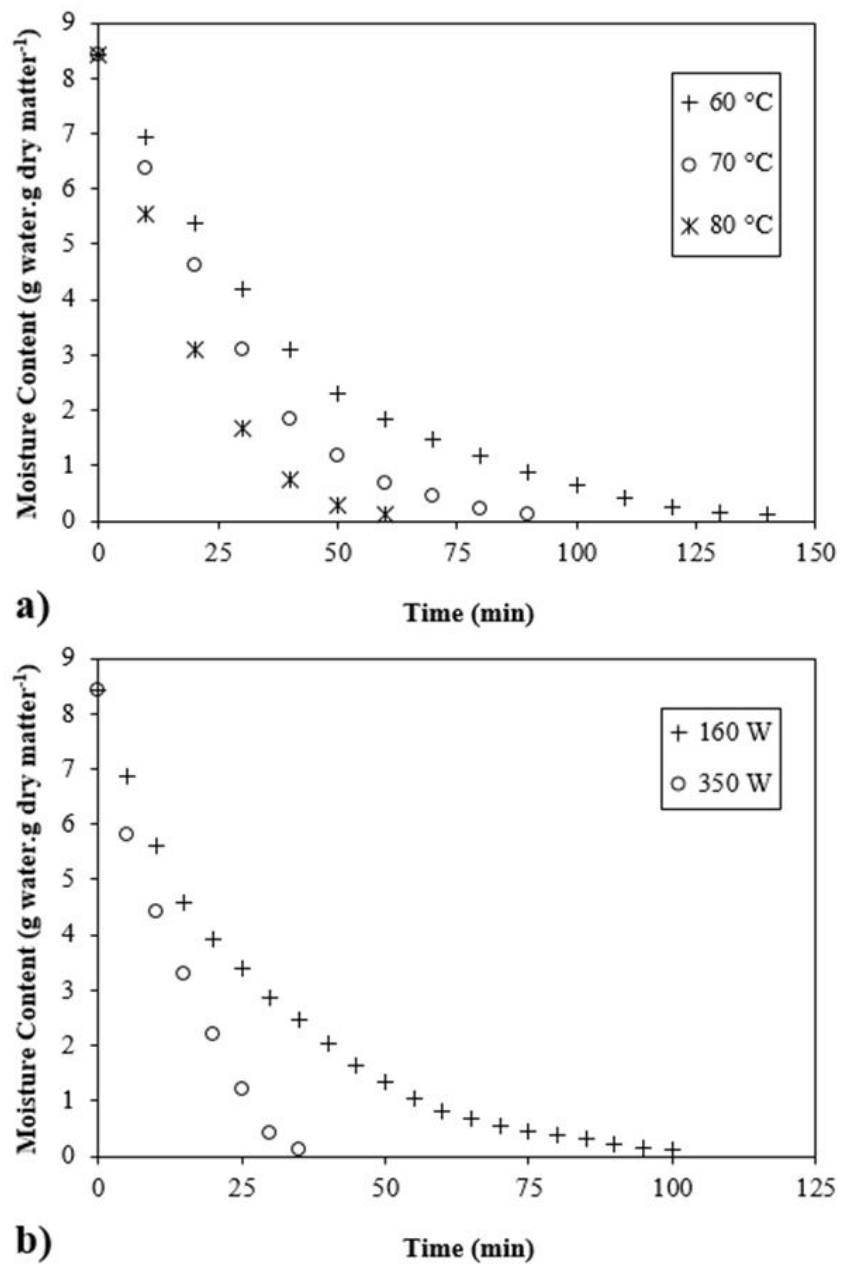

Figure 1. Drying curves of ginger samples at temperatures of the convective method (a) and power levels of the microwave method (b).

highest microwave power might be by reason of a rise in water diffusivity in the tomato slices, i.e., at high microwave power level by reason of the removal of moisture quickly, the drying duration shortened. It can be said that the time essential to dry agricultural products depends on several agents including first and last moisture content of the product, indigenous properties of it, drying conditions and method (Torki-Harchegani et al., 2016).

\subsection{Suitability of drying curves}

The acquired outcomes from the statistical analyses of 9 different thin layer drying models are presented in Table 2, including the comparison criteria that are utilized to assess the appropriateness of the model fit $\left(R M S E, R^{2}\right.$ and $\left.\chi^{2}\right)$ and the coefficients of drying model. In all scenarios, RMSE and $\chi^{2}$ values were smaller than 30.3219 and $0.0555 \times 10^{-4}$, in return, and also $R^{2}$ values were higher than 0.96 , pointing out good fit results. The above-mentioned results reveal that the whole thin layer drying models used in the research fulfilled the thin layer drying behavior of ginger sufficiently. Comparing the 9 models resulted that the Diffusion Approach $\left(60^{\circ} \mathrm{C}\right)$, Page $\left(70\right.$ and $\left.80^{\circ} \mathrm{C}\right)$ and Midilli et al. (160 and $350 \mathrm{~W}$ ) rendered the best statistical 


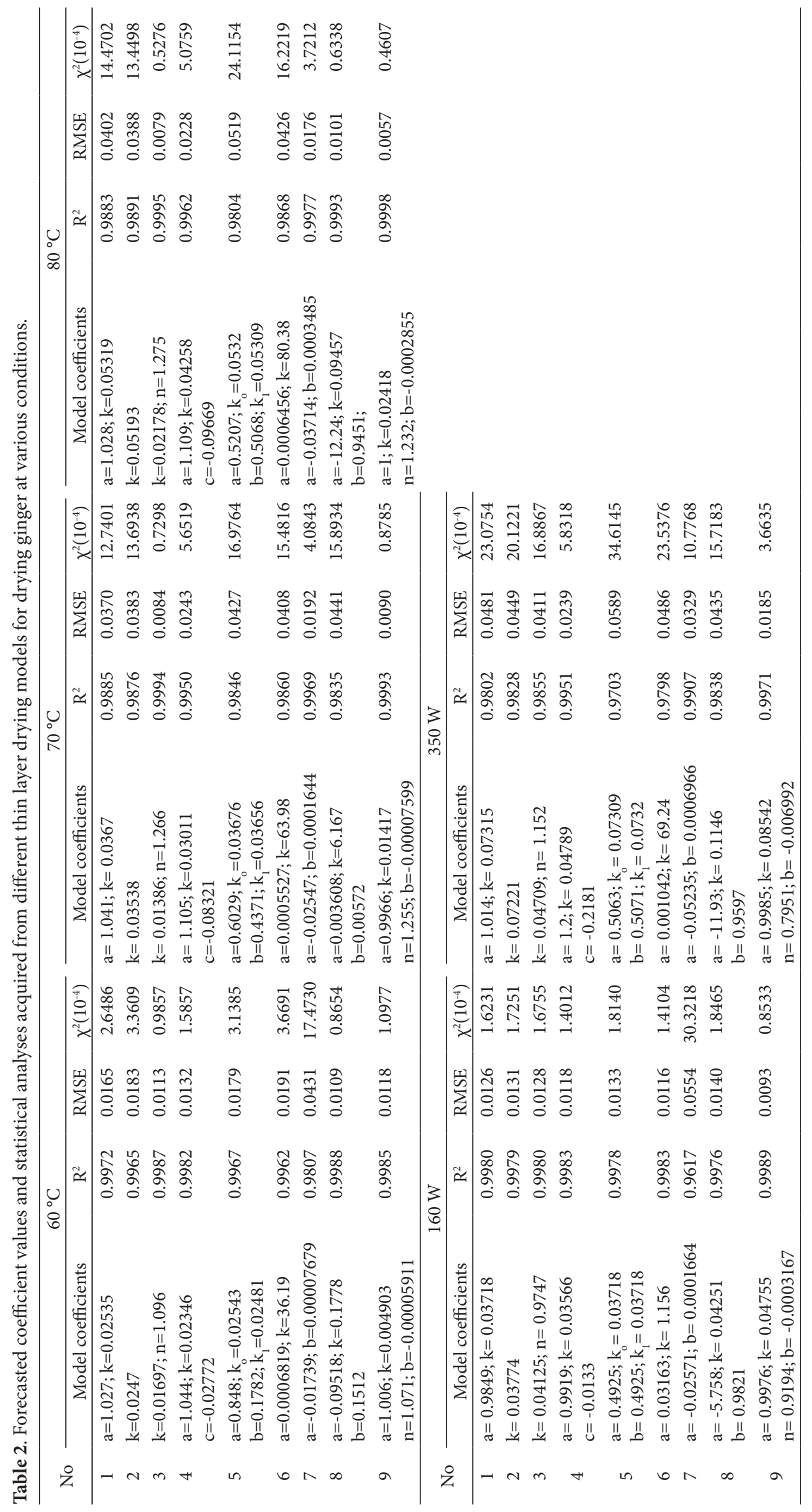


values. For all drying conditions, the $R^{2}, R M S E$ and $\chi^{2}$ values obtained from the Diffusion Approach, Midilli et al. and Page models ranged from 0.9945 to $0.9994,0.0085$ to 0.0262 and $0.7980 \times 10^{-4}$ to $6.0466 \times 10^{-4} ; 0.9979$ to $0.9997,0.0056$ to 0.0164 and $0.2710 \times 10^{-4}$ to $2.5091 \times 10^{-4}$; and 0.9976 to $0.9994,0.0077$ to 0.0172 and $0.5810 \times 10^{-4}$ to $2.8417 \times 10^{-4}$, in return. Based on these results, Diffusion Approach, Midilli et al. and Page models may be considered to exhibit the thin-layer drying behavior of the ginger samples.

Figure 2 depicts the differentiation of experimental and estimated moisture ratio of dried ginger by using best fit convenient models together with drying duration under chosen temperatures and application of microwave power. Obviously, the results obtained from the Diffusion Approach, Midilli et al. and Page models and the experimental values are close to each other. It may be deduced that Diffusion Approach, Midilli et al. and Page models could adequately represent the drying curves of ginger under the selected experimental conditions. Furthermore, results of this study are in conformance with earlier ones obtained from the drying of organic tomato (Sacilik et al., 2006), cultured mushroom (Celen et al., 2010) for the Diffusion Approach model,

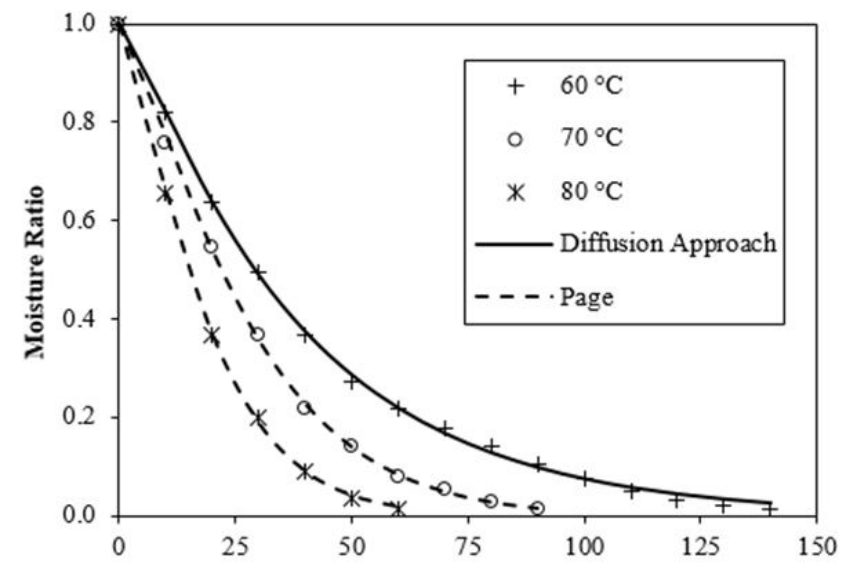

a)

Time (min)

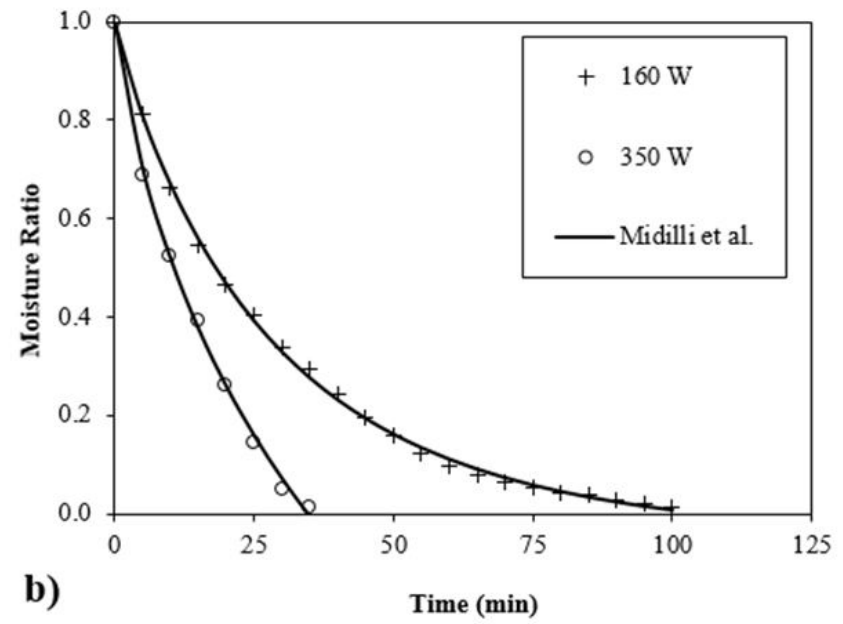

Figure 2. Comparison of theoretical and experimental moisture ratios predicted by the Diffusion Approach, Midilli et al. and Page models under the chosen drying conditions (convective method (a) and microwave method (b)) at particular drying durations. carrot (Doymaz, 2017) and eggplant slices (Kaveh et al., 2017) for Midilli et al. model, walnut (Hassan-Beygi et al., 2009) and onion (Demiray et al., 2017) for Page model.

\subsection{Color changes}

The primary quality parameter for food is the surface color of it as consumers evaluate it first even before tasting it and consequently, color is a critical factor in acceptance of a product. For all drying applications, the color changes in the fresh samples are shown in Figure 3. For fresh ginger samples, $L^{*}, a^{*}$, and $b^{*}$ values were $67.94,-3.01$ and 44.35 , in return. The drying applications affected the color parameters of the samples at a significant level $(P<0.05)$. For convective drying, while the redness/greenness $\left(a^{*}\right)$ and total color differences $(\Delta \mathrm{E})$ values increased from 1.22 to 1.86 and 12.70 to 17.76 , the lightness $\left(L^{\star}\right)$ and the yellowness/blueness $\left(b^{*}\right)$ values of all samples declined from 61.04 to 56.40 and 34.56 to 31.60 , in return after increasing drying temperatures from 60 to $80^{\circ} \mathrm{C}$. De Jesus Junqueira et al. (2017) observed that a decrease in $L^{\star}, b^{*}$ values (darker and less yellowness) and an increase in $\mathrm{a}^{*}$ values (more reddish) for convective drying of cape gooseberry fruits and explained that this behavior indicates browning reactions. The Maillard reaction products which have brown color are known as a consequence of various pigment formations such as melanoidins (Dehghannya et al., 2017). Aydogdu et al. (2015) remarked that the increase in temperature led to a rise in the reactivity between the amino group and the sugar. Therefore, Maillard reaction rate rises with temperature. In microwave drying, while the $\left(L^{\star}\right)$ value decreased from 61.09 to $57.40, a^{*}, b^{*}$ and $\Delta \mathrm{E}$ values increased from 0.81 to 1.12 and 32.75 to 34.52 and 14.98 to 14.00 , respectively after increasing microwave powers from 160 to $350 \mathrm{~W}$. Resembling trend was observed by Izli et al. (2017) microwave drying application of mango slices at 120 and $350 \mathrm{~W}$. With regard to the dried product, total color difference is crucial, that indicates the ability of human eye to distinguish between the colors of samples (Wojdyło et al., 2014).

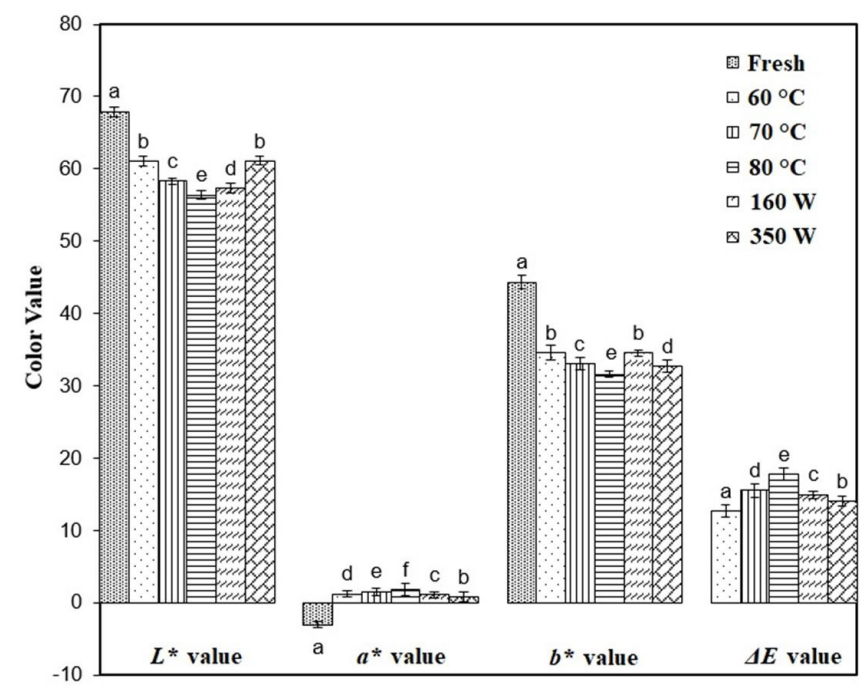

Figure 3. Color values of fresh and dried ginger at various convective drying temperatures and microwave powers. 
In relation of the raise in drying temperature and microwave power, the $\Delta \mathrm{E}$ values of dried samples increase. This situation can also be associated with the impact of high-temperature levels on compounds that are susceptible to heat, including carbohydrates and proteins.

\subsection{Rehydration ratio}

To understand the quality of dried material, rehydration is a crucial attribute. Rehydration may be addressed as a measure of the chemical and physical changes take place in the product in the

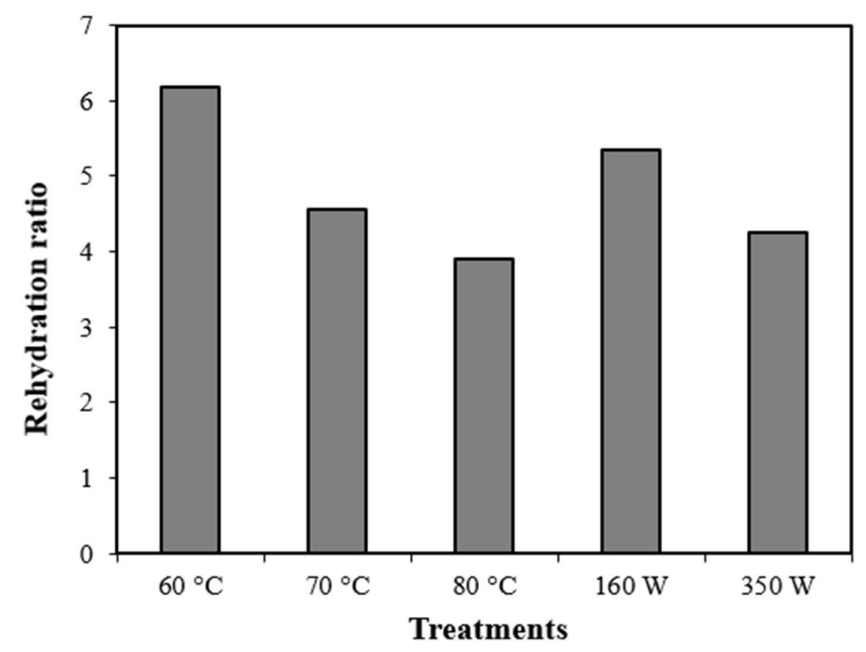

Figure 4. Rehydration ratio values of ginger dried ginger at various convective drying temperatures and microwave power levels. course of the process of drying (Aral \& Beşe, 2016). The rehydration ratio of ginger samples dried at different microwave powers and temperatures is presented in Figure 4. The rehydration ratio of the samples dried at different conditions ranged from 3.9 to 6.18 , with the highest value obtained when the samples were dried at $60^{\circ} \mathrm{C}$ temperature. The results indicated that microwave power and temperature had a considerable impact on rehydration ratio. It is possible to say that rehydration ratio values of dried samples declined with a raise in air drying temperature and microwave power. Sacilik \& Elicin (2006) pointed out that there is an increase in rehydration ratio due to the rise in the drying air temperatures and stated that the reason is that the moisture removal rate is very quick and that induces less contraction of the dried slices and hence this case catalyzes rehydration. Horuz et al. (2017) also asserted that in the course of drying at high microwave power levels, irrevocable cellular dislocation and rupture arise. This ends up with the tissue integrity loss that generates an intense structure of largely shrunken and collapsed capillaries that have diminished hydrophilic properties. This gives lower values for the rehydration values.

\subsection{Microstructural analysis}

Figure 5a-e shows the scanning electron microscope visuals of the dried gingers after applying various drying methods. As it can be seen, there is a clear distinction in terms of microstructure after applying convective drying method at 60,70 and $80^{\circ} \mathrm{C}$, as the samples dried at $80^{\circ} \mathrm{C}$ displaying a deteriorated structure in comparison with the ones dried at 60 and $70^{\circ} \mathrm{C}$. From the point of the microwave drying, structural deformation of the samples was higher at $350 \mathrm{~W}$ compared to that of at $160 \mathrm{~W}$, which may be
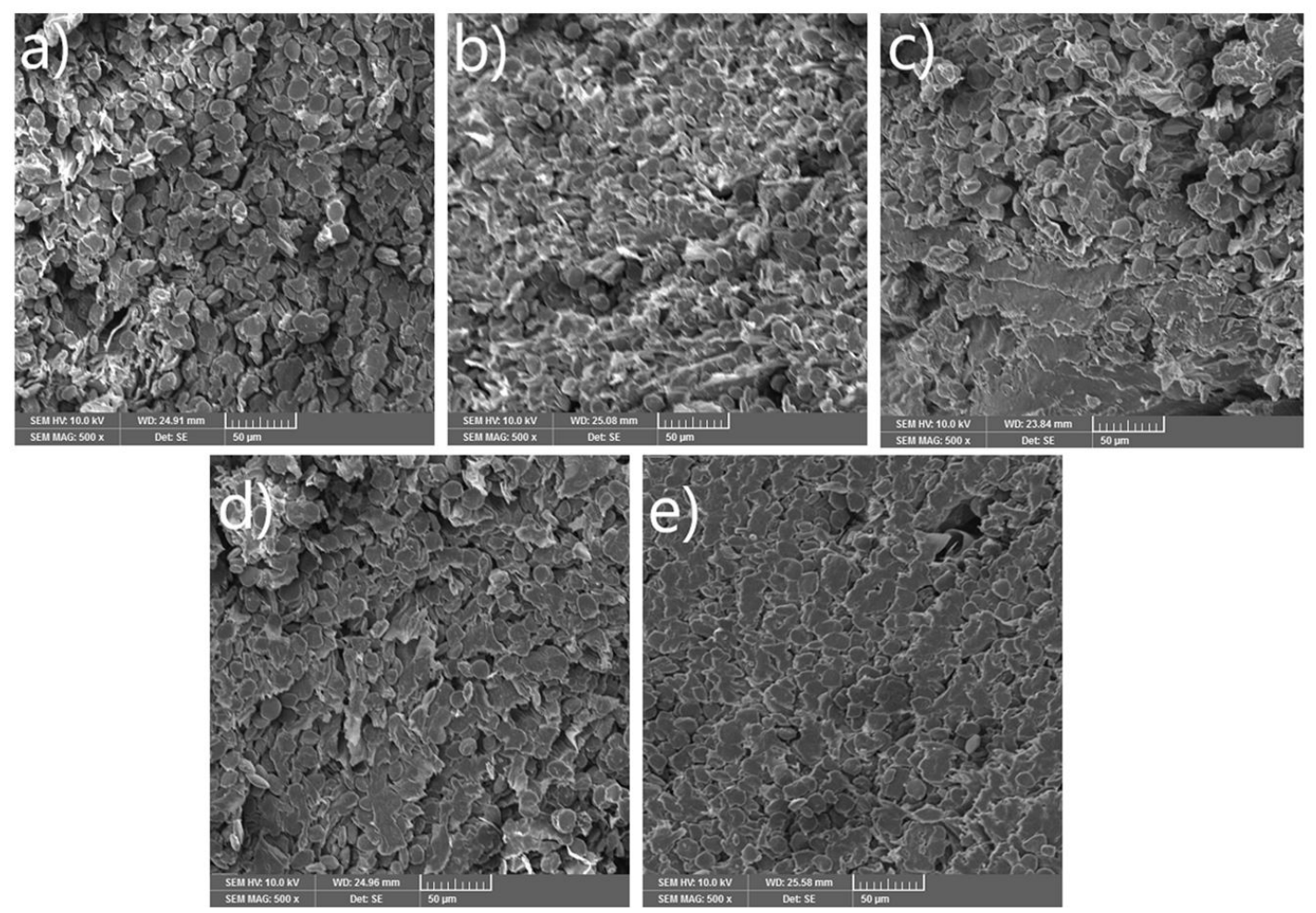

Figure 5. Scanning electron microscopy micrographs of the dried ginger samples: convective drying at 60 (a), 70 (b) and $80^{\circ} \mathrm{C}$ (c) and microwave drying at $160(\mathrm{~d})$ and $350 \mathrm{~W}(\mathrm{e})$. 
because of the fact that higher microwave power causes higher diffusion rate. High-temperature level and high microwave power level in the course of drying led to intensified water evaporation and melting of starch granules in all of the drying conditions. This situation may undermine the starch-protein matrix and hence gives rise to structural damage and finally ruins the samples. In addition, this detriment may be due to the briefer drying duration, greater drying temperature and microwave power levels and enlargement of some tissues due to vaporization of internal water. The results mentioned above were analogous with the findings of the literature and in harmony with the impact of high temperature (Vega-Gálvez et al., 2015) and microwave power (Bal et al., 2017) levels on the dried products' structure.

\section{Conclusion}

This research has inspected the effect of both convective and microwave drying applications on the drying kinetics, color rehydration ratio and microstructural properties of ginger samples. Additionally, the data of experimental moisture loss was placed to 9 thin-layer drying models. The longest and shortest drying durations were achieved by using convective drying method at $60{ }^{\circ} \mathrm{C}$ (140 minutes) and also microwave drying method at $350 \mathrm{~W}$ (35 minutes) power level, in return. It is apparent that a surge in the drying air temperature and microwave power level enabled a downfall in drying durations. Among the used thin layer drying models, Diffusion approach, Midilli et al. and Page models presented the best figuration of the experimental data. The convective drying application at $60{ }^{\circ} \mathrm{C}$ produced the best color values for the product that was nearest to the $\mathrm{L}^{\star}$ and $\mathrm{b}^{*}$ values of it. The rehydration properties improved when the gingers were dried at lower hot air temperatures microwave power levels. In addition, the scanning electron microscopy visuals put forward that greater drying temperature or microwave power entailed microstructure deformation of the ginger samples. The present study has obtained results which depict that convective and microwave drying methods are feasible alternatives for drying ginger.

\section{References}

Akpinar, E. K., \& Toraman, S. (2016). Determination of drying kinetics and convective heat transfer coefficients of ginger slices. Heat and Mass Transfer, 52(10), 2271-2281. http://dx.doi.org/10.1007/ s00231-015-1729-6.

An, K., Zhao, D., Wang, Z., Wu, J., Xu, Y., \& Xiao, G. (2016). Comparison of different drying methods on Chinese ginger (Zingiber officinale Roscoe): Changes in volatiles, chemical profile, antioxidant properties, and microstructure. Food Chemistry, 197(Pt B), 1292-1300. http:// dx.doi.org/10.1016/j.foodchem.2015.11.033. PMid:26675871.

Aral, S., \& Beşe, A. V. (2016). Convective drying of hawthorn fruit (Crataegus spp.): effect of experimental parameters on drying kinetics, color, shrinkage, and rehydration capacity. Food Chemistry, 210, 577-584. http://dx.doi.org/10.1016/j.foodchem.2016.04.128. PMid:27211684.

Aydogdu, A., Sumnu, G., \& Sahin, S. (2015). Effects of microwaveinfrared combination drying on quality of eggplants. Food and Bioprocess Technology, 8(6), 1198-1210. http://dx.doi.org/10.1007/ s11947-015-1484-1.

Bal, L. M., Yogranjan, Naik, S. N., Satya, S., \& Kar, A. (2017). Changes in tissue structure and physico-chemical quality characteristics of bamboo shoot slices during microwave drying process. Journal of Food Measurement and Characterization, 11(3), 1203-1209. http:// dx.doi.org/10.1007/s11694-017-9497-2.

Beigi, M. (2016). Hot air drying of apple slices: dehydration characteristics and quality assessment. Heat and Mass Transfer, 52(8), 1435-1442. http://dx.doi.org/10.1007/s00231-015-1646-8.

Bondaruk, J., Markowski, M., \& Błaszczak, W. (2007). Effect of drying conditions on the quality of vacuum-microwave dried potato cubes. Journal of Food Engineering, 81(2), 306-312. http://dx.doi. org/10.1016/j.jfoodeng.2006.10.028.

Celen, S., Kahveci, K., Akyol, U., \& Haksever, A. (2010). Drying behavior of cultured mushrooms. Journal of Food Processing and Preservation, 34(1), 27-42. http://dx.doi.org/10.1111/j.1745-4549.2008.00300.x.

Coşkun, S., Doymaz, İ., Tunçkal, C., \& Erdoğan, S. (2017). Investigation of drying kinetics of tomato slices dried by using a closed loop heat pump dryer. Heat and Mass Transfer, 53(6), 1863-1871. http://dx.doi. org/10.1007/s00231-016-1946-7.

Dehghannya, J., Gorbani, R., \& Ghanbarzadeh, B. (2017). Influence of combined pretreatments on color parameters during convective drying of Mirabelle plum (Prunus domestica subsp. syriaca). Heat and Mass Transfer, 53(7), 2425-2433. http://dx.doi.org/10.1007/ s00231-017-1995-6.

Demiray, E., Seker, A., \& Tulek, Y. (2017). Drying kinetics of onion (Allium cepa L.) slices with convective and microwave drying. Heat and Mass Transfer, 53(5), 1817-1827. http://dx.doi.org/10.1007/ s00231-016-1943-X.

Deshmukh, A. W., Varma, M. N., Yoo, C. K., \& Wasewar, K. L. (2013). Effect of ethyl oleate pretreatment on drying of ginger: characteristics and mathematical modelling. Journal of Chemistry, 2013, 1-6. http:// dx.doi.org/10.1155/2013/890384.

Doymaz, İ. (2012). Evaluation of some thin-layer drying models of persimmon slices (Diospyros kaki L.). Energy Conversion and Management, 56, 199-205. http://dx.doi.org/10.1016/j.enconman.2011.11.027.

Doymaz, İ. (2017). Drying kinetics, rehydration and colour characteristics of convective hot-air drying of carrot slices. Heat and Mass Transfer, 53(1), 25-35. http://dx.doi.org/10.1007/s00231-016-1791-8.

Giri, S. K., \& Prasad, S. (2007). Drying kinetics and rehydration characteristics of microwave-vacuum and convective hot-air dried mushrooms. Journal of Food Engineering, 78(2), 512-521. http:// dx.doi.org/10.1016/j.jfoodeng.2005.10.021.

Hassan-Beygi, S. R., Aghbashlo, M., Kianmehr, M. H., \& Massah, J. (2009). Drying characteristics of walnut (Juglans regia L.) during convection drying. International Agrophysics, 23(2), 129-135.

Horuz, E., \& Maskan, M. (2015). Hot air and microwave drying of pomegranate (Punica granatum L.) arils. Journal of Food Science and Technology, 52(1), 285-293. http://dx.doi.org/10.1007/s13197013-1032-9.

Horuz, E., Jaafar, H. J., \& Maskan, M. (2017). Ultrasonication as pretreatment for drying of tomato slices in a hot air-microwave hybrid oven. Drying Technology, 35(7), 849-859. http://dx.doi.org/ 10.1080/07373937.2016.1222538.

Izli, N., Izli, G., \& Taskin, O. (2017). Influence of different drying techniques on drying parameters of mango. Food Science and Technology (Campinas), 37(4), 604-612. http://dx.doi.org/10.1590/1678$457 x .28316$.

Junqueira, J. R. J., Corrêa, J. L. G., Oliveira, H. M., Ivo Soares Avelar, R., \& Salles Pio, L. A. (2017). Convective drying of cape gooseberry fruits: Effect of pretreatments on kinetics and quality parameters. Lebensmittel-Wissenschaft + Technologie, 82, 404-410. http://dx.doi. org/10.1016/j.lwt.2017.04.072. 
Kaveh, M., Amiri Chayjan, R., \& Nikbakht, A. M. (2017). Mass transfer characteristics of eggplant slices during length of continuous band dryer. Heat and Mass Transfer, 53(6), 2045-2059. http://dx.doi. org/10.1007/s00231-016-1961-8.

Oikonomopoulou, V. P., \& Krokida, M. K. (2012). Structural properties of dried potatoes, mushrooms, and strawberries as a function of freeze-drying pressure. Drying Technology, 30(4), 351-361. http:// dx.doi.org/10.1080/07373937.2011.639475.

Parlak, N. (2015). Fluidized bed drying characteristics and modeling of ginger (zingiber officinale) slices. Heat and Mass Transfer, 51(8), 1085-1095. http://dx.doi.org/10.1007/s00231-014-1480-4.

$\mathrm{Pu}, \mathrm{H}$., Li, Z., Hui, J., \& Raghavan, G. V. (2016). Effect of relative humidity on microwave drying of carrot. Journal of Food Engineering, 190, 167-175. http://dx.doi.org/10.1016/j.jfoodeng.2016.06.027.

Sacilik, K., \& Elicin, A. K. (2006). The thin layer drying characteristics of organic apple slices. Journal of Food Engineering, 73(3), 281-289. http://dx.doi.org/10.1016/j.jfoodeng.2005.03.024.

Sacilik, K., Keskin, R., \& Elicin, A. K. (2006). Mathematical modelling of solar tunnel drying of thin layer organic tomato. Journal of Food Engineering, 73(3), 231-238. http://dx.doi.org/10.1016/j. jfoodeng.2005.01.025.

Simon-Brown, K., Solval, K. M., Chotiko, A., Alfaro, L., Reyes, V., Liu, C., Dzandu, B., Kyereh, E., Goldson Barnaby, A., Thompson, I., Xu, Z., \& Sathivel, S. (2016). Microencapsulation of ginger (Zingiber officinale) extract by spray drying technology. Lebensmittel-Wissenschaft + Technologie, 70, 119-125. http://dx.doi.org/10.1016/j.lwt.2016.02.030.

Raghavan, G. S. V., Sunjka, P. S., \& Orsat, V. (2008). Microwave/ vacuum drying of Cranberries (Vacccinium macrocarpon). American Journal Food Technology, 3(2), 100-108. http://dx.doi.org/10.3923/ ajft.2008.100.108.

Thorat, I. D., Mohapatra, D., Sutar, R. F., Kapdi, S. S., \& Jagtap, D. D. (2012). Mathematical modeling and experimental study on thin-layer vacuum drying of ginger (Zingiber officinale R.) slices. Food and
Bioprocess Technology, 5(4), 1379-1383. http://dx.doi.org/10.1007/ s11947-010-0429-y.

Tian, Y., Zhao, Y., Huang, J., Zeng, H., \& Zheng, B. (2016). Effects of different drying methods on the product quality and volatile compounds of whole shiitake mushrooms. Food Chemistry, 197(Pt A), 714-722. http://dx.doi.org/10.1016/j.foodchem.2015.11.029. PMid:26617008.

Torki-Harchegani, M., Ghasemi-Varnamkhasti, M., Ghanbarian, D., Sadeghi, M., \& Tohidi, M. (2016). Dehydration characteristics and mathematical modelling of lemon slices drying undergoing oven treatment. Heat and Mass Transfer, 52(2), 281-289. http://dx.doi. org/10.1007/s00231-015-1546-y.

Vega-Gálvez, A., Zura-Bravo, L., Lemus-Mondaca, R., Martinez-Monzó, J., Quispe-Fuentes, I., Puente, L., \& Di Scala, K. (2015). Influence of drying temperature on dietary fibre, rehydration properties, texture and microstructure of Cape gooseberry (Physalis peruviana L.). Journal of Food Science and Technology, 52(4), 2304-2311. http:// dx.doi.org/10.1007/s13197-013-1235-0. PMid:25829613.

Wojdyło, A., Figiel, A., Lech, K., Nowicka, P., \& Oszmiański, J. (2014). Effect of convective and vacuum-microwave drying on the bioactive compounds, color, and antioxidant capacity of sour cherries. Food and Bioprocess Technology, 7(3), 829-841. http://dx.doi.org/10.1007/ s11947-013-1130-8.

Wojdyło, A., Figiel, A., Legua, P., Lech, K., Carbonell-Barrachina, Á. A., \& Hernández, F. (2016). Chemical composition, antioxidant capacity, and sensory quality of dried jujube fruits as affected by cultivar and drying method. Food Chemistry, 207, 170-179. http:// dx.doi.org/10.1016/j.foodchem.2016.03.099. PMid:27080894.

Zielinska, M., Sadowski, P., \& Błaszczak, W. (2015). Freezing/thawing and microwave-assisted drying of blueberries (Vaccinium corymbosum L.). Lebensmittel-Wissenschaft + Technologie, 62(1), 555-563. http:// dx.doi.org/10.1016/j.lwt.2014.08.002. 